\title{
FAKTOR-FAKTOR YANG BERHUBUNGAN DENGAN KEMANDIRIAN LANSIA DALAM MELAKUKAN PERSONAL HYGIENEDI PANTI SOSIAL TERATAI
}

\author{
Abu Bakar Sidik ${ }^{1}$ \\ ${ }^{1}$ Program Studi Ilmu Keperawatan STIK Bina Husada Palembang
}

\begin{abstract}
Factors Relating to the Independence of the Elderly in Performing Personal Hygiene at Panti Sosial Teratai. Daily life Activities in English term is abbreviated as ADL (activity of daily living) is a primary activity for self-care. In other words, the amount of support needed in daily life activities as well as to plan longterm care. Cleanliness is part of a person's appearance and self-confidence so that if someone has limitations in fulfilling the needs of personal hygiene may affect his general health. It can be understood that people, at the age above 55 years the aging process occurs naturally. This raises various problems of physical, mental, social, economic, and psychological health. These include things of keeping the health of the body and the environment. The independence in taking care of himself can be judged by its ability to perform activities without supervision, direction, or being helped by someone else, such as showering, dressing, going to toilet and doing other activities there, move (move from the floor to the chair, from chair to bed, walking, go up and down stairs, can control bowel movements (properly), and can feed themselves well (eg, food is not in a mess). The purpose of the study was to determine the factors associated with the independence of elderly in performing personal hygiene in Social Institutions Tresna Werdha Wargatama Palembang on the date of 3 April-10 Juli, 2018. It used quantitative design with a cross sectional approach. Samples of this research were elderlies who lived in Social Institutions Tresna Teratai Palembang 2018 which amounted to 64 respondents. The result shows the frequency distribution of the majority of respondents had a good knowledge of were 45 people $(70.3 \%)$, the majority of respondents have independence were 36 people $(56.3 \%)$ and the majority of respondents have good personal hygiene were 48 people $(75,0 \%)$. There was a relationship between knowledge and the personal hygiene of the elderlies in Social Institutions Teratai Palembang 2018 ( $\rho=0.003)$. There was a relationship between independence and personal hygiene of the elderlies in Social Institutions Teratai Palembang 2018 ( $\rho=0.040$ ). Suggested to the manager of Social Institutions Teratai Palembang to always improve the quality of service by giving the right direction about personal hygiene through socialization and posters about personal hygiene to residents so that they can know the importance of personal hygiene much better.
\end{abstract}

Keywords: Independence, Knowledge, Personal Hygiene

\begin{abstract}
Abstrak: Faktor-Faktor Yang Berhubungan Dengan Kemandirian Lansia Dalam Melakukan Personal Hygiene Di Panti Sosial Teratai. Aktivitas kehidupan harian yang dalam istilah bahasa Inggris disingkat ADL (activity of daily living) adalah merupakan aktivitas pokok bagi perawatan diri. Dengan kata lain, besarnya bantuan yang diperlukan dalam aktivitas kehidupan sehari- hari serta untuk menyusun rencana perawatan jangka panjang. Kebersihan seseorang merupakan bagian dari penampilan dan harga diri sehingga jika seseorang mengalami keterbatasan dalam pemenuhan kebutuhan personal hygiene bisa jadi akan mempengaruhi kesehatan secara umum, dapat diketahui bahwa secara individu, pada usia di atas 55 tahun terjadi proses penuaan secara alamiah. Hal ini menimbulkan berbagai masalah baik fisik,
\end{abstract}


mental, sosial, ekonomi dan psikologis, kesehatan. Hal ini termasuk menjaga kebersihan tubuh dan lingkungan. Kemandirian di dalam mengurus diri sendiri dapat dinilai dari kemampuannya melakukan aktivitas tanpa pengawasan, pengarahan atau bantuan orang lain, seperti mandi, berpakaian rapi, pergi ke toilet dan melakukan sendiri aktivitas, berpindah tempat (berpindah dari lantai ke kursi, dari kursi ke tempat tidur, berjalan, naik dan turun tangga, dapat mengontrol buang air besar dan kecil (tidak beser), dan dapat makan sendiri dengan baik (misalnya makanan tidak berserakan di sekitarnya). Penelitian ini bertujuan untuk mengetahui faktor-faktor yang berhubungan dengan kemandirian lansia dalam melakukan personal hygiene di Panti Sosial Teratai Palembang Tahun 2018. Desain penelitian ini menggunakan desain kuantitatif dengan pendekatan cross sectional. Teknik pemilihan sampel dengan menggunakan total populasi 64 responden. pada tanggal 3 april - 10 Juli Tahun 2018. Analisis statistic menggunakan uji chi-square dengan nilai $p$ value $=0,05$. Hasil penelitian ini menunjukkan distribusi frekuensi responden sebagian besar memiliki pengetahuan baik sebanyak 45 orang $(70,3 \%)$, sebagian besar responden memiliki kemandirian sebanyak 36 orang $(56,3 \%)$ dan sebagian besar responden memiliki personal hygiene baik sebanyak 48 orang $(75,0 \%)$. Ada hubungan pengetahuan dengan personal hygiene pada lansia di Panti Sosial Teratai Palembang Tahun $2018(\rho=0,003)$. Ada hubungan kemandirian dengan personal hygiene pada lansia di Panti Sosial Teratai Palembang Tahun $201 \quad(\rho=0,040)$. Disarankan kepada pihak pengelola Panti Sosial Teratai Palembang untuk selalu meningkatkan mutu pelayanan dengan memberikan pengarahan-pengarahan tentang kebersihan diri melalui sosialisasi maupun poster-poster tentang kebersihan diri kepada penghuni panti agar pengetahuan penghuni panti tentang pentingnya kebersihan diri semakin baik lagi.

Kata Kunci: Kemandirian, Pengetahuan, Personal Hygiene

\section{PENDAHULUAN}

Lanjut usia adalah seseorang yang usianya lanjut 55 tahun keatas, mengalami perubahan biologis, fisik, kejiwaan, dan sosial. Menurut UndangUndangNomor 13 Tahun 1998 dalam Bab I Pasal 1 Ayat 2 yang berbunyi "Lanjut usia adalah seseorang yang mencapai usia 60 tahun ke atas. Menurut UU kesehatan No 36 Tahun 2009 pasal 138 menegaskan, kesehatan lanjut usia perlu mendapat perhatian khusus dengan tetap dipelihara|dan ditingkatkan agar selama mungkin dapat hidup secara produktif sesuai dengan kemampuan nya sehingga dapat ikut serta dalam berperan aktif dalam pembangunan (Depsos, 2012).

Di seluruh dunia jumlah orang lanjut usia diperkirakan ada 500 juta dengan usia rata-rata 60 tahun dan diperkirakan pada tahun 2025 akan mencapai 1,2 milyar. Pada tahun 2020 $20 \%$ dari populasi Amerika akan berusia 65 tahun, dengan pertumbuhan terbesar populasi diantara usia 85 tahun ke atas. Hampir 75 juta penduduk Amerika lahir antara tahun 1946 dan 1964 (Stanley, 2012).

Transisi demografi pada kelompok lansia terkait dengan status kesehatan lansia yang lebih terjamin, sehingga usia harapan hidup lansia lebih tinggi dibanding masa-masa sebelumnya. Pertambahan jumlah lansia di Indonesia dalam kurun waktu tahun 1990 sampai 2025, tergolong tercepat di dunia. Bila dilihat lansia berdasarkan jenis kelamin, penduduk lansia yang paling banyak adalah perempuan, Menurut data Kementerian Kesehatan RI pada tahun 2013, jumlah Lansia laki- laki sebanyak $6,9 \%$ dan Lansia 
perempuan sebanyak $8,2 \%$. Hal ini menunjukkan bahwa umur harapan hidup yang paling tinggi adalah perempuan (Kemenkes RI, 2013).

Perkembangan Penduduk Lanjut usia (lansia) di Indonesia menarik untuk diamati. Dari tahun ke tahun jumlahnya cenderung meningkat. Pada tahun 2010 penduduk lansia di Indonesia 23,9 juta atau $9,77 \%$ dan UHH sekitar 67,4 tahun. Sepuluh tahun kemudian atau pada 2020 perkiraan penduduk lansia di Indonesia mencapai 28,8 juta atau $11,34 \%$ dengan UHH sekitar 71,1 tahun. Diperkirakan Tahun 2020-2025 Indonesia akan menduduki peringkat keempat dunia setelah China, India, dan Amerika Serikat (Nugroho, 2013).

Faktor penyebab kurangnya perawatan diri pada lansia diakibatkan kurangnya pengetahuan atau deficit kognitif. Di Indonesia, belum didukung oleh adanya peningkatan kualitas pelayanan kesehatan pada lansia. Pengetahuan perawatan lansia, baik oleh keluarga, lansia itu sendiri maupun lembaga sosial lainnya masih sangat kurang memadai (Hurlock, 2012).

Kemandirian di dalam mengurus diri sendiri dapat dinilai dari kemampuannya melakukan. Aktivitas sehari-hari tanpa pengawasan, pengarahan atau bantuan orang lain, seperti mandi, berpakaian rapi, pergi ke toilet dan melakukan sendiri aktivitas disana, berpindah tempat (berpindah dari lantai ke kursi, dari kursi ke tempat tidur, berjalan, naik dan turun tangga, dapat mengontrol buang air besar dan kecil (tidak beser), dan dapat makan sendiri dengan baik (misalnya makanan tidak berserakan di sekitarnya). Salah satu kriteria orang mandiri adalah dapat mengaktualisasikan dirinya (self actualized) tidak menggantungkan kepuasan- kepuasan utama pada lingkungan dan kepada orang lain. Mereka lebih tergantung pada potensipotensi mereka sendiri bagi perkembangan dan kelangsungan pertumbuhannya (Maryam dkk, 2012).

Hasil penelitian Wisudaningsih (2012), dalam penelitian tentang hubungan kemandirian lansia dengan personal hygiene pada lansia di Unit Rehabilitasi Sosial Dewanata Cilacap, didapatkan hasil sebagian besar responden mandiri sebanyak 35 responden $(77,8 \%)$, sebagian besar personal hygiene responden adalah sedang sebanyak 24responden $(53,3 \%)$, Ada hubungan kemandirian lansia dengan personal hygiene pada lansia dengan $\mathrm{X} 2$ hitung $>\mathrm{X} 2$ tabel $(25,136>5,991)$ maka Ho ditolak dan Ha diterima.

Berdasarkan survey pendahuluan yang dilakukan oleh peneliti di Panti Sosial TerataiPalembang, jumlah Iansia pada tahun 2015 sebanyak 70 orang, pada tahun 2016 sebanyak 62 orang, pada tahun 2017 sebanyak 60 orang dan pada bulan tahun 2018 sebanyak 64 orang. Berdasarkan latar belakang diatas, penulis tertarik untuk meneliti tentang faktor-faktor yang berhubungan dengan kemandirian lansia dalam melakukan personal hygiene di Panti Sosial Teratai Palembang Tahun 2018. Pertama diketahuinya faktorfaktor yang berhubungan dengan kemandirian lansia dalam melakukan personal hygiene di Panti Sosial Teratai Palembang Tahun 2018. Kedua diketahuinya distribusi tingkat pengetahuan, tingkat kemandirian dan personal hygiene pada lansia di Panti Sosial Teratai Palembang Tahun 2018. Ketiga diketahuinya hubungan pengetahuan dengan personal hygiene pada lansia di Panti Sosial Teratai Palembang Tahun 2018. Keempat diketahuinya hubungan tingkat kemandirian dengan personal hygiene pada lansia di Panti Sosial Teratai Palembang Tahun 2016. 


\section{METODE}

Penelitian yang digunakan yaitu penelitiankuantitatif survey analitik dengan pendekatan cross sectional untuk mempelajari dinamika korelasi antara hubungan dengan efek dengan cara pengumpulan data dilakukan dengan menggunakan kuesioner, Penelitian ini dilakukan di Panti Sosial Teratai Palembang pada tanggal 3 April- 10 Juli Tahun 2018. Pemilihan sampel dalam penelitian ini dengan total berjumlah 64 responden,hipotesis dalam penelitian ini adalah Ada hubungan pengetahuan dan tingkat kemandirian dengan personal hygiene pada lansia di Panti Sosial Teratai Palembang Tahun 2018. Penelitian ini difokuskan untuk mengetahui faktor-faktor yang berhubungan dengan kemandirian lansia dalam melakukan personal hygiene dan yang menjadi sampel penelitian adalah lansia di Panti Sosial Teratai Palembang. Analisis statistic dengan uji chi-square dengan niali kemaknaan $p$ value $=0.05$

\section{HASIL}

\section{Karakteristik responden}

Hasil penelitian menunjukkan

responden menurut pengetahuan setelah dikategorikan terlihat dalam tabel dibawah ini.

Tabel 1. Distribusi Frekuensi Responden Berdasarkan Pengetahuan di Panti Sosial Teratai Palembang

\begin{tabular}{llll}
\hline No & Pengetahuan & Jumlah & Persentase \\
& & & \\
\hline 1 & & 45 & $70,3 \%$ \\
2 & Kurang Baik & 19 & $29,7 \%$ \\
\hline & Total & $\mathbf{6 4}$ & $\mathbf{1 0 0 \%}$ \\
\hline
\end{tabular}

Berdasarkan tabel di atas, dapat diketahui bahwa responden yang memiliki pengetahuan baik jika dibandingkan dengan responden yang memiliki pengetahuan kurang baik yaitu sebanyak 19 orang $(29,7 \%)$ dari 64 responden.

Penelitian ini selaras dengan penelitian Zakariya (2012) tentang faktor-faktor yang kemandirian pada lanjut usia di Panti Sosial Tresna Werdha (PSTW) Budi Mulia 04 Margaguna Jakarta Selatan, didapatkan hasil uji statistik didapatkan $P$ value sebesar 0,028 , artinya $P>0,05$ dapat disimpulkan tidak ada antara hubungan kemandirian dengan personal hygiene pada lansia. Pengetahuan merupakan hasil dari tahu, dan ini terjadi setelah orang melakukan pengindraan terhadap suatu objek tertentu. Penginderaan terjadi melalui pancaindra manusia, yakni indra penglihatan, pendengaran, penciuman, rasa, dan raba. Sebagian besar pengetahuan manusiadiperoleh melalui mata dan telinga. Pengetahuanatau ranah kognitif merupakan domain yang sangat penting dalam membentuk tindakan seseorang (overt behaviour). Tingkat Pengetahuan di dalam Domain Kognitif Pengetahuan yang tercakup dalam domain kognitif mempunyai enam tingkatan sebagai berikut (Notoatmodjo, 2012).

Kemudian, berdasarkan tabel 1 , didapatkan data yang menjelaskan bahwa pengetahuan oleh lansia ada hubungan dengan personal hygiene, hal tersebut menunjukan bahwa pengetahuan dengan personal hygiene pada lansia terbukti statistik. 
Tabel 2. Distribusi Frekuensi Responden Berdasarkan Kemandirian di Panti Sosial Teratai Palembang

\begin{tabular}{clrl}
\hline No & Kemandirian & Jumlah & Persentase \\
\hline 1 & Tidak mandiri & 28 & $43,8 \%$ \\
2 & Mandiri & 36 & $56,3 \%$ \\
\hline \multicolumn{2}{c}{ Total } & $\mathbf{6 4}$ & $\mathbf{1 0 0} \%$ \\
\hline
\end{tabular}

Berdasarkan tabel di atas, dapat diketahui bahwa responden yang memiliki kemandirian sebanyak 36 orang $(56,3 \%)$, lebih banyak jikadibandingkan dengan responden yang tidak mandiri yaitu sebanyak 28 orang $(43,8 \%)$ dari 64 responden. Hasil penelitian ini sejalan dengan penelitian yang dilakukan oleh Zakariya (2012), tentang faktor-faktor yang kemandirian pada lanjut usia di Panti Sosial Tresna Werdha (PSTW) Budi Mulia 04 Margaguna Jakarta Selatan, didapatkan hasil uji statistik didapatkan $\mathrm{P}$ value sebesar 0,028 , artinya $P>0,05$ dapat disimpulkan tidak ada antara hubungan kemandirian dengan personal hygiene pada lansia.

Berdasarkan hasil penelitian, teori yang ada, peneliti berpendapat bahwa keadaan seseorang yang dapat menentukan diri sendiri dimana dapat dinyatakan dalam tindakan atau perilaku seseorang, selain itu juga dibutuhkan bantuan dalam proses kemandirian. Hasil penelitian menunjukkan distribusi frekuensi responden menurut personal hygiene setelah dikategorikan terlihat dalam tabel berikut ini.

Tabel 3. Distribusi Frekuensi Responden Berdasarkan Personal Hygiene di Panti Sosial Teratai Palembang

\begin{tabular}{cccc}
\hline No & Personal hygiene & Jumlah & Persentase \\
\hline 1 & Baik & 48 & $75,0 \%$ \\
2 & Tidak Baik & 16 & $25,0 \%$ \\
\hline & Total & $\mathbf{6 4}$ & $\mathbf{1 0 0} \%$
\end{tabular}

Berdasarkan tabel diatas, dapat diketahui bahwa responden yang memiliki personal hygiene baik sebanyak 48 orang $(75,0 \%)$, lebih banyak jika dibandingkan dengan responden yang memiliki personal hygiene kurang baik yaitu sebanyak 16 orang $(25,0 \%)$ dari 64 responden.

Perawatan diri atau kebersihan diri (personal hygiene) merupakan perawatan diri sendiri yang dilakukan untuk mempertahankan kesehatan, baik secara fisik maupun psikologis. Pemenuhan perawatan diri dipengaruhi berbagai faktor, diantaranya budaya, nilai sosial pada individu atau keluarga, pengetahuan terhadap perawatan diri serta persepsi terhadap perawatan diri (Heriana, 2014).
Hasil penelitian ini sejalan dengan penelitian yang dilakukan oleh Zakariya (2012), tentang faktor-faktor yang kemandirian pada lanjut usia di Panti Sosial Tresna Werdha (PSTW) Budi Mulia 04Margaguna Jakarta Selatan, didapatkan hasil uji statistik didapatkan $\mathrm{P}$ value sebesar 0,028, artinya $\mathrm{P}>0,05$ dapat disimpulkan tidak ada antara hubungan kemandirian dengan personal hygiene pada lansia.

Kemudian, berdasarkan tabel 3 didapatkan data yang menjelaskan bahwa kemandirian oleh lansia ada hubungan denganpersonal hygiene, hal tersebut menunjukan bahwa kemandirian dengan personal hygiene pada lansia terbukti statistik. 
2. Hubungan Antara Pengetahuan Dengan Personal Hygiene

Analisa bivariat dilakukan dengan tabulasisilang (crosstab) dan uji chisquare untuk menemukan bentuk hubungan statistik antara variabel independen pengetahuan dengan variabledependen (personal hygiene). Hasil analisis bivariat menemukan hubungan antara masing-masing variabel independen dan variabel dependen.

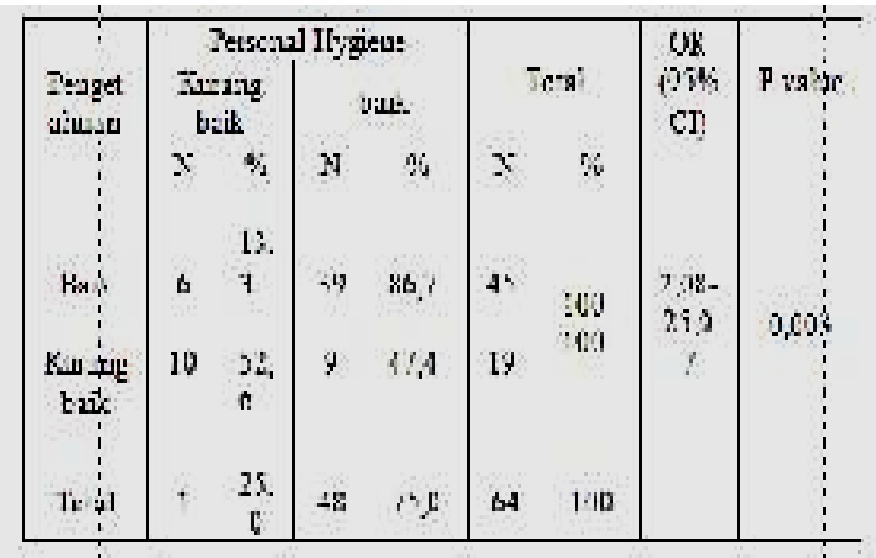

Gambar 1. Hubungan antara Pengetahuan dengan Personal Hygiene di Panti Sosial Teratai Palembang

\begin{abstract}
Berdasarkan gambar diatas, dari 45 responden yang memiliki
\end{abstract} pengetahuan baik sebanyak 39 responden $(86,7 \%)$ yang personal hygiene kurang baik 6 responden $(13,3 \%)$. Hasil uji statistik chi square didapatkan $\rho$ value $=0,003(95 \%)$ ada hubungan antara pengetahuan dengan personal hygiene di Panti Sosial Teratai Palembang Tahun 2018. Responden yang memiliki pengetahuan kurang baik mempunyai peluang $(\mathrm{OR})=7,22$ kali memiliki personal hygiene kurang baik dibandingkan dengan responden yang memiliki pengetahuan baik.

Dari hasil penelitian yang dilakukan didapatkan didapatkan responden yang memiliki personal hygiene kurang baik dan tidak mandiri sebanyak 11 orang $(39,3 \%)$, lebih banyak jika dibandingkan dengan responden yang memiliki personal hygiene kurang baik dan memiliki kemandirian yaitu sebanyak 5 orang $(13,9 \%)$ dari16 responden $(25,0 \%)$. Hasil uji statistik chi square didapatkan $\rho$ value $=0,040$, yang jika dibandingkandengan nilai $a=0,05$, maka $\rho$ value $\leq 0,05$, sehingga Hipotesis $\mathrm{Nol}$
(Ho) ditolak, Hipotesis Alternatif ( $\mathrm{Ha})$ diterima. Ini berarti ada hubungan yang bermakna antara kemandirian dengan personal hygiene pada lansia di Panti Sosial Tresna Wedha Teratai Palembang Tahun 2018. Dengan demikian hipotesis yang menyatakan ada hubungan kemandirian dengan personal hygiene pada lansia terbukti secara statistic. Sejalan dengan teori yang dikemukakan oleh Notoatmodjo (2012) yang menyatakan bahwa pengetahuan merupakan hasil "tahu" dan ini terjadi setelah orang mengadakan penginderaan terhadap suatu objek tertentu. Penginderaan terhadap objek terjadi melalui panca indra manusia yakni penglihatan, pendengaran, penciuman, rasa dan raba dengan sendiri. Pada waktu penginderaan sampai menghasilkan pengetahuan tersebut sangat dipengaruhi oleh intensitas perhatian persepsi terhadap objek. Sebagian besar pengetahuan manusia diperoleh melalui mata dan telinga.

Hasil penelitian ini tidak jauh berbeda dari penelitian yang dilakukan oleh Zakariya (2012), tentang faktor- 
faktor yang berhubungan dengan kemandirian pada lanjut usia di Panti Sosial Tresna Werdha (PSTW) Budi Mulia 04 Margaguna Jakarta Selatan, didapatkan hasil uji statistik didapatkan $\mathrm{P}$ value sebesar 0,028 , artinya $P>0,05$ dapat

disimpulkantidakadahubunganantarakem andirian dengan kemandirian personal hygiene pada lansia.Dari hasil penelitian yang dilakukan didapatkan responden yang memiliki personal hygiene kurang baik dan memiliki pengetahuan kurang baik sebanyak 10 orang $(52,6 \%)$, lebih banyak jika dibandingkan dengan responden yang memiliki personal hygiene kurang baik dan memiliki pengetahuan baik yaitu sebanyak 6 orang $(13,3 \%)$ dari 16 responden $(25,0 \%)$. Hasil uji statistik chi square didapatkan $\rho$ value $=0,003$, yang jika dibandingkan dengan nilai $a=0,05$, maka $\rho$ value $\leq 0,05$, sehingga
Hipotesis Nol (Ho) ditolak, Hipotesis Alternatif $(\mathrm{Ha})$ diterima. Ini berarti ada hubungan yang bermakna antara pengetahuan dengan personal hygiene pada lansia di Panti Sosial Teratai Palembang Tahun 2018.Dengan demikian hipotesis yang menyatakan ada hubungan pengetahuan dengan personal hygiene pada lansia terbukti secara statistik.

\section{Hubungan \\ Kemandirian DenganPersonal Hygiene}

Analisa bivariat dilakukan dengan tabulasisilang (crosstab) dan uji chi-square untuk menemukan bentuk hubungan statistik antara variabel independen kemandirian dengan variabel dependen (personal hygiene). Hasil analisis bivariat menemukan hubungan antara masing-masing variabel independen dan variabel dependen.

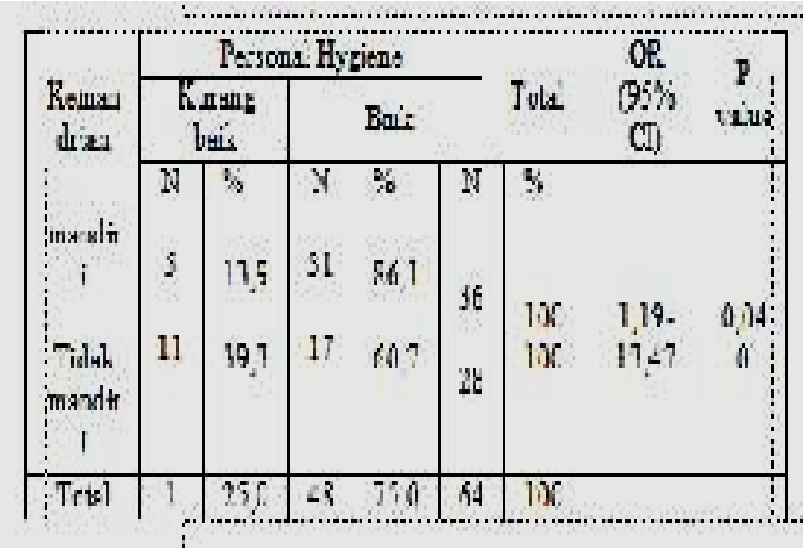

\section{Gambar 2. Hubungan antara kemandirian dengan Personal Hygiene di Panti}

Sosial

Dari gambar diatas, dari 36 responden yang memiliki kemandirian baik sebanyak 31 responden $(86,1 \%)$ yang personal hygiene kurang baik 5 responden $(13,9 \%)$. Hasil uji statistik chi square didapatkan $\rho$ value $=0,040$ (95) ada hubungan antara kemandirian dengan personal hygiene di Panti Sosial Teratai Palembang Tahun 2018. Responden yang tidak mandiri mempunyai peluang OR 4,01 kali memiliki personal hygiene kurang baik dibandingkan dengan responden yang mandiri.

Dari hasil penelitian yang dilakukan didapatkan didapatkan responden yang memiliki personal hygiene kurang baik dan tidak mandiri sebanyak 11 orang $(39,3 \%)$, lebih banyak jika dibandingkan dengan responden yang memiliki personal hygiene kurang baik dan memilikikemandirian yaitu sebanyak 5 
orang $(13,9 \%)$ dari16 responden $(25,0 \%)$. Hasil uji statistik chi squaredidapatkan $\rho$ value $=0,040$, yang jika dibandingkan dengan nilai $a=0,05$, maka $\rho$ value $\leq 0,05$, sehingga Hipotesis Nol (Ho) ditolak, Hipotesis Alternatif ( $\mathrm{Ha}$ ) diterima. Ini berarti ada hubungan yang bermakna antara kemandirian dengan personal hygiene pada lansia di Panti Sosial Tresna Wedha Teratai Palembang Tahun 2018. Dengan demikian hipotesis yang menyatakan ada hubungan kemandirian dengan personal hygiene pada lansia terbukti secara statistik.

Hasil penelitian ini tidak jauh berbeda dari penelitian yang dilakukan oleh Zakariya (2012), tentang faktorfaktor yang berhubungan dengan kemandirian pada lanjut usia di Panti Sosial Tresna Werdha (PSTW) Budi Mulia 04 Margaguna Jakarta Selatan, didapatkan hasil uji statistik didapatkan $\mathrm{P}$ value sebesar 0,028, artinya $P>0,05$ dapat disimpulkan tidak ada hubungan antara kemandirian dengan kemandirian personal hygiene pada lansia.

Berdasarkan hasil penelitian yang ada dapat dibuat kesimpulan bahwa ada hubungan yang bermakna antara kemandirian dengan personal hygiene pada lansia. Berdasarkan hal tersebut di atas, maka peneliti berasumsi bahwa hasil dari penelitian ini telah menunjukkan bahwa lebih separuh dari responden melakukan tindakan terhadap personal hygiene dengan baik. Hal ini mungkin juga telah didukung oleh tersedianya prasarana atau fasilitas seperti kamar mandi dan sumber air yang bersih di panti tersebut karena tanpa fasilitas yang cukup akan dapat menghambat responden dari dapat melakukan tindakan yang baik. Namun begitu, tindakan yang dilakukan oleh lansia ini mungkin sekedar tindakan yang dilakukan berdasarkan praktik terpimpin yaitu tindakan yang telah dilakukan tetapi masih bergantung pada petugas panti dan tuntunan dalam hal melakukan kemandirian.

\section{PEMBAHASAN}

\section{Karakteristik responden}

Pengetahuan merupakan hasil dari tahu, dan ini terjadi setelah orang melakukan pengindraan terhadap suatu objek tertentu. Penginderaan terjadi melalui pancaindra manusia, yakni indra penglihatan, pendengaran, penciuman, rasa, dan raba. Sebagian besar pengetahuan manusiadiperoleh melalui mata dan telinga. Pengetahuanatau ranah kognitif merupakan domain yang sangat penting dalam membentuk tindakan seseorang (overt behaviour). Tingkat Pengetahuan di dalam Domain Kognitif Pengetahuan yang tercakup dalam domain kognitif mempunyai enam tingkatan sebagai berikut (Notoatmodjo, 2012).

Hasil penelitian ini sejalan dengan penelitian yang dilakukan oleh Zakariya (2012), tentang faktor-faktor yang kemandirian pada lanjut usia di Panti Sosial Tresna Werdha (PSTW) Budi Mulia 04Margaguna Jakarta Selatan, didapatkan hasil uji statistik didapatkan $\mathrm{P}$ value sebesar 0,028 , artinya $\mathrm{P}>0,05$ dapat disimpulkan tidak ada antara hubungan kemandirian dengan personal hygiene pada lansia.

\section{Hubungan Antara Pengetahuan Dengan Personal Hygiene}

Dari hasil penelitian yang dilakukan didapatkan didapatkan responden yang memiliki personal hygiene kurang baik dan tidak mandiri sebanyak 11 orang $(39,3 \%)$, lebih banyak jika dibandingkan dengan responden yang memiliki personal hygiene kurang baik dan memiliki kemandirian yaitu sebanyak 5 orang $(13,9 \%)$ dari16 responden $(25,0 \%)$. Hasil uji statistik chi square didapatkan $\rho$ value $=0,040$, yang jika dibandingkandengan nilai $a=0,05$, maka $\rho$ value $\leq 0,05$, sehingga Hipotesis Nol (Ho) ditolak, Hipotesis Alternatif $(\mathrm{Ha})$ diterima. Ini berarti ada hubungan yang bermakna antara 
kemandirian dengan personal hygiene pada lansia di Panti Sosial Tresna Wedha Teratai Palembang Tahun 2018. Dengan demikian hipotesis yang menyatakan ada hubungan kemandirian dengan personal hygiene pada lansia terbukti secara statistik. Sejalan dengan teori yang dikemukakan oleh Notoatmodjo (2012) yang menyatakan bahwa pengetahuan merupakan hasil "tahu" dan ini terjadi setelah orang mengadakan penginderaan terhadap suatu objek tertentu. Penginderaan terhadap objek terjadi melalui panca indra manusia yakni penglihatan, pendengaran, penciuman, rasa dan raba dengan sendiri. Pada waktu penginderaan sampai menghasilkan pengetahuan tersebut sangat dipengaruhi oleh intensitas perhatian persepsi terhadap objek. Sebagian besar pengetahuan manusia diperoleh melalui mata dan telinga.

Hasil penelitian ini tidak jauh berbeda dari penelitian yang dilakukan oleh Zakariya (2012), tentang faktorfaktor yang berhubungan dengan kemandirian pada lanjut usia di Panti Sosial Tresna Werdha (PSTW) Budi Mulia 04 Margaguna Jakarta Selatan, didapatkan hasil uji statistik didapatkan $\mathrm{P}$ value sebesar 0,028 , artinya $P>0,05$ dapat disimpulkan tidak ada hubungan antara kemandirian dengan kemandirian personal hygiene pada lansia.Dari hasil penelitian yang dilakukan didapatkan responden yang memiliki personal hygiene kurang baik dan memiliki pengetahuan kurang baik sebanyak 10 orang $(52,6 \%)$, lebih banyak jika dibandingkan dengan responden yang memiliki personal hygiene kurang baik dan memiliki pengetahuan baik yaitu sebanyak 6 orang $(13,3 \%)$ dari 16 responden $(25,0 \%)$. Hasil uji statistik chi square didapatkan $\rho$ value $=0,003$, yang jika dibandingkan dengan nilai $a=$ 0,05 , maka $\rho$ value $\leq 0,05$, sehingga Hipotesis Nol (Ho) ditolak, Hipotesis Alternatif ( $\mathrm{Ha})$ diterima. Ini berarti ada hubungan yang bermakna antara pengetahuan dengan personal hygiene pada lansia di Panti Sosial Teratai Palembang Tahun 2018.Dengan demikian hipotesis yang menyatakan ada hubungan pengetahuan dengan personal hygiene pada lansia terbukti secara statistik.

\section{Hubungan Antara Kemandirian DenganPersonal Hygiene}

Hasil penelitian ini tidak jauh berbeda dari penelitian yang dilakukan oleh Zakariya (2012), tentang faktorfaktor yang berhubungan dengan kemandirian pada lanjut usia di Panti Sosial Tresna Werdha (PSTW) Budi Mulia 04 Margaguna Jakarta Selatan, didapatkan hasil uji statistik didapatkan $\mathrm{P}$ value sebesar 0,028, artinya $P>0,05$ dapat disimpulkan tidak ada hubungan antara kemandirian dengan kemandirian personal hygiene pada lansia.

Berdasarkan hasil penelitian yang ada dapat dibuat kesimpulan bahwa ada hubungan yang bermakna antara kemandirian dengan personal hygiene pada lansia. Berdasarkan hal tersebut di atas, maka peneliti berasumsi bahwa hasil dari penelitian ini telah menunjukkan bahwa lebih separuh dari responden melakukan tindakan terhadap personal hygiene dengan baik. Hal ini mungkin juga telah didukung oleh tersedianya prasarana atau fasilitas seperti kamar mandi dan sumber air yang bersih di panti tersebut karena tanpa fasilitas yang cukup akan dapat menghambat responden dari dapat melakukan tindakan yang baik. Namun begitu, tindakan yang dilakukan oleh lansia ini mungkin sekedar tindakan yang dilakukan berdasarkan praktik terpimpin yaitu tindakan yang telah dilakukan tetapi masih bergantung pada petugas panti dan tuntunan dalam hal melakukan kemandirian.

\section{KESIMPULAN}

Dari penelitian diatas disimpulkan bahwa pertama distribusi frekuensi responden sebagian besar memiliki 
pengetahuan baik sebanyak 45 orang $(70,3 \%)$, sebagian besar responden memiliki kemandirian sebanyak36 orang $(56,3 \%)$ dan sebagian besar responden responden memiliki personal hygiene baik sebanyak 48 orang $(75,0 \%)$ dari 64 responden. Kedua terdapat hubungan pengetahuan dengan personal hygiene pada lansia di Panti Sosial Teratai Palembang Tahun 2018 dengan nilai $p$ value $(0,003)$, dan ketiga adanya hubungan kemandirian dengan personal hygiene pada lansia di Panti Sosial Teratai Palembang Tahun 2018 dengan nilai $p$ value $(0,040)$.

\section{SARAN}

Diharapkan kepada pihak pengelola PantiSosial Tratai Palembang untuk selalu meningkatkan mutu pelayanan dandapatmeningkatkan pengetahuan pada lansia tentang kesehatan terutama personal hygiene dengan memberikan pengarahan-pengarahan tentang kebersihan diri melalui sosialisasi maupun poster- poster tentang kebersihan diri kepada penghuni panti agar pengetahuan penghuni panti tentang pentingnya kebersihan diri semakin baik lagi, diharapkan STIK Bina Husada melengkapi referensi buku-buku mengenai konsep khususnya mengenai keperawatan gerontik personal hygiene guna menunjang penelitian baik dosen dan mahasiswa dalam menyelesaikan penelitian, Bagi Peneliti selanjutnya diharapkan dapat melanjutkan penelitian ini sehingga menjadi sempurna. Peneliti menganjurkan dan berharap kepada peneliti selanjutnya untuk meneliti faktor-faktor yang mempengaruhi personal hygiene pada lansia dengan membandingkan pada dua tempat dan menggunakan metode yang berbeda sehingga penelitian ini dapat menjadi sempurna.

\section{DAFTAR PUSTAKA}

Depsos. (2012). Pekerja Sosial Profesional dan Pelayanan Lanjut
Usia dalam Panti. Didapatkan Dari : www.kemsos.go.id. Diakses Tanggal : 02Juli 2016.

Heriana. (2014). Buku Ajar Kebutuhan Dasar Manusia. Tangerang: BinaRupa Aksara.

Hurlock. (2012). Psikologi Perkembangan. Jakarta: EMS.

Kemenkes RI. (2013). Gambaran Kesehatan Lanjut Usia di Indonesia. Jakarta: Kementerian Kesehatan RI.

Maryam dkk. (2012). Mengenal Usia Lanjut Dan Perawatannya. Jakarta: Salemba Medika.

Mubarok. (2010). IImu Keperawatan Komunitas Konsep dan Aplikasi. Jakarta: Salemba Medika

Notoatmodjo Soekidjo. (2012). Promosi Kesehatan dan IImu Perilaku Edisi Revisi. Jakarta: Rineka Cipta.

Nugroho. (2013). Keperawatan Gerontik dan Geriatrik. Jakarta :EGC.

Stanley. (2012). Buku Ajar Keperawatan Gerontik. Jakarta :EGC.

Wisudaningsih. (2012). Hubungan Kemandirian Lansia dengan Personal Hygiene pada Lansia di Unit Rehabilitasi Sosial Dewanata Cilacap. Purwokerto: Universitas Harapan Bangsa. http://respository.uhb.ac.id

Zakariya. (2012). Faktor-Faktor yang Berhubungan dengan Kemandirian pada Lanjut Usia di Panti Sosial Tresna Werdha (PSTW). Budi Mulia Margaguna Jakarta Selatan. Jakarta :Budi Mulia. http://uinjkt.ac.id 